\title{
PELATIHAN JURNALISME WARGA SEBAGAI SARANA PENGEMBANGAN BAKAT REMAJA DALAM DUNIA DIGITAL SERTA PROMOSI PARIWISATA DESA SAMIRAN KECAMATAN SELO KABUPATEN BOYOLALI
}

\author{
Muhammad Muttaqien ${ }^{1}$, Linda Kusumastuti Wardana ${ }^{2}$ \\ Ilmu Komunikasi, Fakultas Ilmu Sosial dan Politik \\ Universitas Muhammadiyah Yogyakarta \\ Jl. Brawijaya, Geblagan, Tamantirto, Kec. Kasihan, Bantul, D.I.Yogyakarta \\ Email : 1 muttaqienmuhammad@gmail.com , ${ }^{2}$ lindawardana25@gmail.com
}

Received: Mei 2020; Accepted : Juni 2020; Published : Juli 2020

\begin{abstract}
Abstrak
Konsep pariwisata berkelanjutan mulai banyak digunakan guna mendukung perkembangan perekonomian di daerah yang memiliki potensi wisata, salah satunya dengan cara menawarkan pemandangan yang indah, yang nantinya juga akan mendatangkan perekonomian untuk masyarakat di sekitar. Desa Samiran berada di Kecamatan Selo, Kabupaten Boyolali, Jawa Tengah merupakan salah satu desa yang memiliki potensi pariwisata yang selain menawarkan keindahan panorama alam juga memiliki potensi lain seperti pertanian, homestay dan kesenian. Namun permasalahannya adalah kurangnya pemanfaatan potensi warga sebagai sumber untuk menciptakan materi promosi yang murah dan mudah. Oleh karena itu, pengabdian ini bertujuan untuk memberi pengetahuan kepada masyarakat khususnya remaja untuk bersama-sama memanfaatkan kekuatan media elektronik sebagai sarana promosi. Kegiatan yang dilakukan adalah pelatihan dan pendampingan pembuatan konten video jurnalisme warga. Pada pengabdian ini akan mengajak masyarakat Desa Samiran untuk belajar menjadi jurnalis warga, yang nantinya akan digunakan sebagai media promosi yang bisa dipublish di media social, baik Instagram, youtube, facebook dan lainnya. Metode yang digunakan melalui tiga tahapan yaitu perencanaan, pelaksanaan dan evaluasi.
\end{abstract}

Kata kunci : Jurnalisme warga, Internet, Samiran, Pariwisata

\begin{abstract}
The concept of sustainable tourism is widely used to support economic development in areas that have tourism potential, one of them by offering a beautiful view, that will also bring the economy to the people around. Samiran village located in Selo Sub-district, Boyolali district, central java, is one of the villages with the potential tourism, as long as it offers natural panorama also has another potential like agriculture, homestay, and art. But the problem is the lack of utilizing potential citizens as a source to create promotional materials that are cheap and easy. Therefore, this dedication was to be giving knowledge to people especially teenagers to together using the power of electronic media as promotional tools. The activities undertaken are training and mentoring the creation of journalism video content. This dedication will invite the people of village Samiran to learn to be citizen journalism, which will be used as promotional
\end{abstract}


media that can be published on social media, like Instagram, Youtube, Facebook, etc. The method used through three-phase is planning, implementation, and evaluation.

Keyword : citizen journalism, internet, Samiran, tourism

\section{Latar belakang masalah}

Sumber daya alam adalah sesuatu hal yang bisa dimanfaatkan dan diolah menjadi pariwisata dengan cara menawarkan pemandangan yang indah, yang nantinya juga akan mendatangkan perekonomian untuk masyarakat di sekitar. Pariwisata sebagai suatu proses kepergian sementara dari seseorang atau lebih menuju tempat lain di luar tempat tinggalnya. Dorongan kepergiannya adalah karena berbagai kepentingan, baik karena kepentingan ekonomi, sosial, kebudayaan, politik, agama, kesehatan maupun kepentingan lain seperti karena sekedar ingin tahu, menambah pengalaman ataupun untuk belajar [1]. Dewasa ini, konsep sustainable tourism atau pariwisata berkelanjutan mulai banyak digunakan guna mendukung perkembangan perekonomian di daerah yang memiliki potensi wisata dengan cara mempertimbangkan kebutuhan saat ini tanpa meninggalkan kemampuan generasi pada masa mendatang. Pariwisata berkelanjutan adalah konsep mengunjungi suatu tempat sebagai seorang wisatawan dan berusaha membuat dampak positif terhadap lingkungan, masyarakat, dan ekonomi [2].

Samiran adalah desa yang berada di Kecamatan Selo, Kabupaten Boyolali, Jawa Tengah merupakan salah satu desa yang memiliki potensi pariwisata yang menawarkan keindahan panorama alam karena letak desa Samiran juga berada di bawah lereng gunung Merapi. Desa Samiran merupakan salah satu dari 10 desa yang ada di Kecamatan Selo Kabupaten Boyolali yang terbagi menjadi 4 pendusunan dan 12 pedukuhan yaitu Dukuh Pentongan dan Kuncen yang berada di Dusun I, Dukuh Ngablak, Salam dan Tegal Sruni yang berada di Dusun II, Dukuh Ngaglik, Jaranan dan Segaran yang berada di Dusun III, dan yang terakhir adalah Dukuh Gebyok, Tretes, Samiran dan Citakan yang berada di Dusun IV.

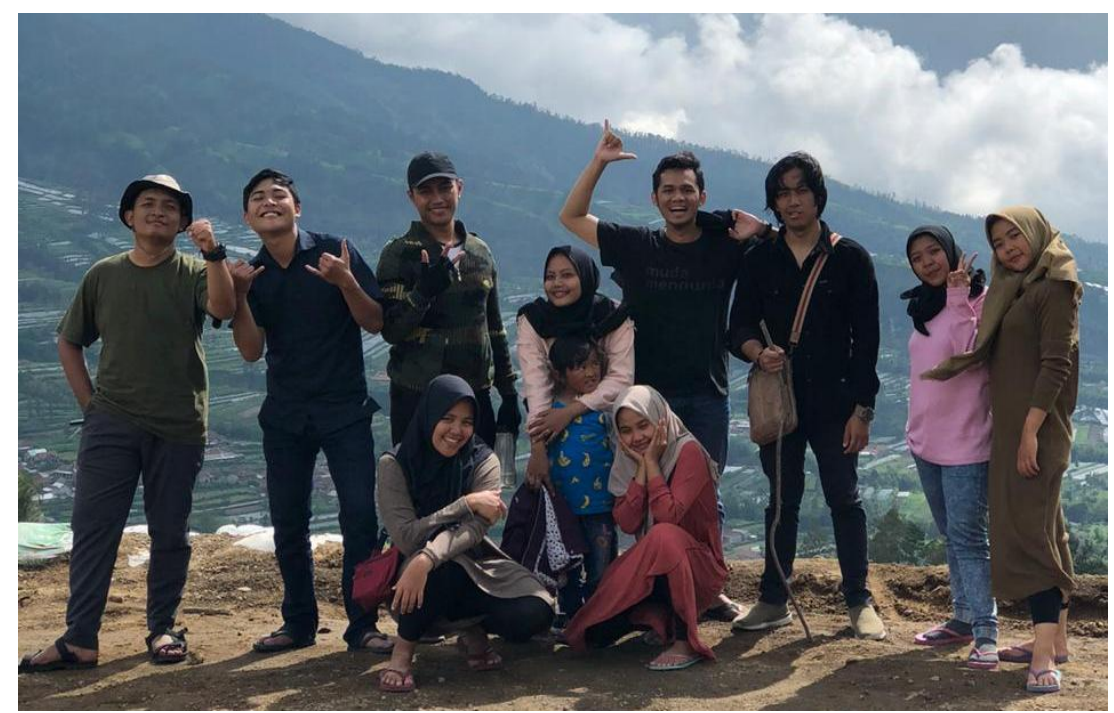

Gambar 1. Salah satu tempat foto di Samiran

Desa Samiran merupakan desa berkembang yang terletak diantara dua gunung ternama yaitu Gunung Merapi dan Gunung Merbabu. Letak Desa Samiran juga cukup strategis dikarenakan letaknya yang berdekatan dengan jalan alternatif utama penghubung magelang138

Volume 3, Nomor 2, Juli 2020 
boyolali. Daerah ini juga sering kali dilewati oleh para pendaki yang ingin melakukan pendakian di Gunung Merbabu atau Gunung Merapi. Hingga saat ini, warga desa Samiran selalu berbenah untuk mengembangkan pariwisata yang ada, salah satunya dengan cara mengelola rumah menjadi homestay dan memanfaatkan pertanian, dan seni tari sebagai salah satu daya tarik pariwisata tersebut. Dengan adanya pariwisata maka perekonomian warga Samiran akan semakin membaik.

Pengabdian dilakukan di 2 dusun yang berada di Samiran, yaitu dusun II dan dusun III. Di Dusun II terdiri dari 2 RW dan 9 RT yang tersebar di Dukuh Ngablak, Salam dan Tegal Sruni yang mana mayoritas masyarakatnya menjadi petani dan peternak. Selain itu, dusun II juga memiliki seni tari yang diberi nama Turonggo Seto sebagai salah satu daya tarik. Sedangkan Dusun III terdiri dari 10 RT yang tergabung dalam 2 RW. Sumber Daya Alam yang dihasilkan dari Dusun III diantaranya yaitu sayuran seperti, wortel, kol, brokoli, dan kentang. Selain bertani, mayoritas masyarakat Dusun III bekerja pada sektor wisata, diantaranya yaitu wisata merapi garden, embung manajar, simpang selo, pos pengamatan merapi, goa raja, petilasan kebokanigoro, dan petik sayur. Dusun III khususnya Dukuh Ngaglik juga merupakan pusat homestay, sehingga menambah daya tarik wisatawan untuk berkunjung ke dusun ini. Wisatawan dapat memilih paket wisata yang telah disediakan oleh desa wisata Samiran, diantaranya adalah ready made, regional, dan by custome.

Hal yang menjadi daya tarik untuk mendatangkan wisatawan tidak hanya dengan memanfaatkan sumber alam yang sudah ada namun juga membutuhkan media untuk promosi, salah satunya adalah dengan memanfaatkan teknologi yang berkembang khususnya internet atau media online. Media online atau new media merupakan media yang tersaji secara online di situs web internet. Hal baru yang tersaji pada new media yaitu akses informasi kapanpun dan dimanapun diseluruh dunia, selama memiliki perangkat dengan koneksi internet [3].

Desa Wisata Samiran Boyolali atau disebut dengan istilah DeWi SamBi sudah melakukan promosi melalui dua skema, yaitu secara konvensional berbasis cetak dan modern berbasis internet. Untuk konvensional sudah dilakukan melalui pembagian brosur, kegiatan pameran, roadshow dan mouth to mouth. Kemudian untuk kegiatan modern sudah dilakukan melalui website, hingga kerjasama dengan aplikasi perjalanan. Namun untuk kebutuhan konten yang akan di unggah di media sosial masih sangat rendah. Jika dimanfaatkan dengan baik, media sosial bisa menjadi alat promosi hemat biaya, dan lebih efisien. Media sosial dapat digunakan secara masif dan juga lebih efektif serta efisien karena media sosial dilihat dapat lebih menghemat pengeluaran dan juga waktu daripada menggunakan media yang konvensional yang harus menggunakan banyak biaya dan waktu yang di gunakan seperti media cetak koran atau media tv dan radio [4].

Dalam melakukan promosi terutama untuk pengembangan pariwisata, harus mendapatkan support yang baik dari warga atau masyarakat dalam bentuk keterlibatan menjalankan program pengembangan pariwisata khususnya Desa Samiran. Keikutsertaan masyarakat dalam proses pengidentifikasian masalah dan potensi yang ada di masyarakat, pemilihan dan pengambilan keputusan tentang alternatif solusi untuk menangani masalah, pelaksanaan upaya mengatasi masalah, dan keterlibatan masyarkat dalam proses mengevaluasi perubahan yang terjadi [5]. Masyarakat harus dilibatkan demi menjalankan kegiatan pengembangan pariwisata, karena parisipasi dari masyarakat tidak bisa dipisahkan. Local people participationis aprerequisite for sustainable tourism [6].

Berdasarkan uraian diatas, maka pengabdian ini bertujuan untuk bersama-sama dengan 
masyarakat untuk membuat promosi pariwisata desa Samiran dengan cara mengedukasi dan membekali masyarakat khususnya remaja untuk memanfaatkan media social sebagai media promosi yang sangat cepat dengan cara pembuatan video dengan menggunakan smartphone. Pada pengabdian ini akan mengajak masyarakat Samiran untuk belajar menjadi jurnalis warga atau citizen journalism yang selanjutnya disebut $C J$, yang nantinya akan digunakan sebagai media promosi yang bisa dipublish di media social, baik Instagram, youtube, facebook dan lainnya. $C J$ merupakan suatu bentuk kegiatan jurnalistik yang melibatkan warga masyarakat untuk ikut mengisi media. Warga masyarakat diberikan kebebasan untuk memberitakan dan melaporkan peristiwa atau kejadian yang dekat dengan lokasi tempat tinggalnya. Artinya, siapa saja, baik ibu rumah tangga, Pegawai Negeri Sipil, pelajar, militer, maupun usahawan, dengan menggunakan teknologi informasi yang tersambung ke internet, dapat meliput dan mendistribusikan atau mengirimkan berita ke media massa [7].

Kehadiran $C J$ dapat membantu dalam pemenuhan kebutuhan masyarakat luas akan informasi yang dibutuhkan, dalam hal ini adalah informasi tentang desa wisata Samiran. CJ dapat berjalan dengan baik ketika masyarakat, yang kemudian disebut dengan istilah citizens memahami fungsi dan tujuan dari $C J$ itu sendiri dan mampu bekerjasama memberikan kontribusi untuk keberlangsungan promosi pariwisata desa Samiran. Citizens sebagai sekelompok warga yang aktif memberikan kontribusi berita seiring dengan perkembangan internet. Menurutnya Citizen harus memahami nilai - nilai kerja kolektif dan aspek-aspek yang harus dimiliki dalam menjalankan proses komunikasi publik.[8]

Target dan luaran dari kegiatan ini adalah masyarakat Samiran mampu mengembangkan bakat dan keahlian dalam memberikan informasi berbentuk media audio visual kepada khalayak umum dengan cara menjadi $C J$ yang akan memberikan informasi terkait pariwisata baik dari segi fasilitas yang ditawarkan hingga kehidupan sehari-hari masyarakat desa Samiran. Daya tarik dibagi menjadi 3 kategori, yakni natural attraction (berdasarkan pada bentukan lingkungan alami), cultural attraction (aktivitas manusia), dan special types of attraction (atraksi buatan seperti themepark, circus, dan shopping). [9]

Kegiatan yang dilakukan antara lain melakukan sosialisasi dengan menjelaskan tentang $C J$ serta melakukan pelatihan dan pendampingan pembuatan video $C J$ dengan menggunakan handphone atau gadget agar masyarakat memiliki bekal untuk proses pembuatan konten berita di kemudian hari. Seorang pewarta warga tidak harus menghapal dan mengikuti sama persis ke-17 bekal sebagai jurnalis profesional itu, meski tidak ada salahnya juga jika dilaksanakan. Ke-17 bekal kerja itu adalah : naluri berita, observasi, keingintahuan, mengenal berita, menangani berita, ungkapan yang jelas, kepribadian yang luwes, pendekatan yang sesuai, kecepatan, kecerdikan, teguh pada janji, daya ingat yang tajam, buku catatan, berkas catatan atau referensi, kamus, surat kabar/majalah/internet/televisi/radio [10].

\section{Masalah}

Pengabdian ini dilakukan dengan cara pendampingan pelatihan yang yang didasari oleh permasalah yang ada di mitra yang ada di Desa Samiran, Boyolali :

1) Kurangnya pemanfaatan potensi warga, terutama pemuda dalam meningkatkan kemampuan untuk membuat konten promosi untuk media sosial, yaitu untuk menjadi jurnalis warga atau citizen journalism (CJ) dengan cara membuat video dengan penggunaan smartphone, dengan konten warga sebagai jurnalis yang memberikan informasi mengenai potensi-potensi yang ada di Samiran. 
Pelatihan Jurnalisme Warga Sebagai Sarana Pengembangan Bakat Remaja Dalam Dunia Digital Serta...

2) Terbatasnya informasi tentang cara melakukan promosi melalui media sosial, terutama youtube dan Instagram dengan menggunakan format audiovisual.

\section{Metode}

Metode yang digunakan melalui tiga tahap kegiatan, mulai dari persiapan, pelaksanaan hingga evaluasi.

1. Persiapan

Persiapan yang dilakukan adalah dengan cara observasi sumber daya manusia yang ada di Samiran, Selo, Boyolali. Hal ini dilakukan guna mengetahui seberapa besar kemampuan dan keinginan yang dimiliki oleh masyarakat khususnya pemuda dalam menggunakan smartphone sebagai media promosi. Persiapan dilakukan dengan cara melalukan diskusi dengan perwakilan dari warga atau pemuda dengan menggunakan metode SWOT (Strenghts, Weakness, Opportunities, Threats) agar menemukan visi yang sama dalam menjalankan program.

2. Pelaksanaan

Pada pelaksaan dibagi menjadi beberapa tahap, mulai dari sosialisasi, pelatihan dan pendampingan produksi hingga mengadakan kegiatan malam apresiasi pemutaran karya. Pelaksanaan tahap awal adalah melakukan seminar sosialisasi yang diadakan pada tanggal 26 januari 2020 yang menghadirkan pemuda karang taruna. Dalam kegiatan sosialisasi, pemateri menyampaikan tentang materi jurnalistik dan tujuan dari pembuatan video tersebut. Selain itu juga mencoba untuk menggali potensi pemuda untuk mengembangkan promosi DeWi SamBi (Desa Wisata Samiran Boyolali).

Tahap berikutnya adalah pelatihan dan pendampingan produksi video jurnalisme warga. Pada tahap ini, masyarakat dibagi menjadi beberapa kelompok dan diberikan pelatihan sederhana membuat video dengan menggunakan handphone. Dalam pelatihan ini, selain diberikan pelatihan menggunakan handphone juga diberi tantangan untuk menjadi pembawa acara dalam video tersebut. Setelah pelatihan, kelompok diberi kesempatan dua minggu untuk memproduksi video jurnalisme warga dengan monitoring dari tim pengabdian. Hasil dari produksi video akan dilombakan dan diputar ketika malam apresiasi.

Tahap terakhir dari pelaksaan adalah malam apresiasi pemutaran karya. Acara ini diselenggarakan sebagai tempat untuk mengapresiasi karya-karya video jurnalisme yang telah dibuat oleh warga. Kegiatan ini bekerjasama dengan tim dari bioskop keliling UMY (BioLing UMY) untuk menyediakan alat pemutaran film. Kegiatan dilakukan pada malam hari tanggal 2 maret 2020 dilapangan utama samiran. Karya terkumpul sebanyak 7 video yang semuanya diputar kemudian diambil 3 pemenang yang dipilih oleh ketua pengabdian, sebagai dosen dan praktiksi audiovisual. Turonggo Seto sebagai salah satu komunitas tari di Samiran diundang untuk melakukan pertunjukan penutup acara.

3. Evaluasi

Tahap terakhir yang dilakukan adalah evaluasi dengan cara melakukan diskusi dengan warga tentang hasil program yang sudah dilaksanakan, apakah tercapai atau tidak. Indikator capaian dinilai dari seberapa paham warga tentang fungsi dari media sosial untuk kebutuhan promosi, khususnya adalah peran penting warga untuk menjadi jurnalis warga dengan menggunakan alat sederhana yaitu smartphone. 


\section{Hasil dan Pembahasan}

Hasil dari Kegiatan ini adalah sebagai bentuk sharing ilmu pengetahuan dan pemahaman untuk dapat meningkatkan keterampilan masyarakat Desa Samiran dalam mempromosikan potensi wisata yang ada melalui media sosial dalam bentuk jurnalistik warga dengan menggunakan alat bantu handphone atau gadget. Kegiatan diawali survei dan diskusi dengan warga Desa Samiran, dengan menggunakan metode SWOT (Strenghts, Weakness, Opportunities, Threats) untuk mengetahui potensi dan rancangan kegiatan yang harus dilakukan, dengan temuan sebagai berikut:

1. Strengths (kekuatan) :

Sumber daya alam atau pemandangan yang ditawarkan terbilang bagus, mulai dari pegunungan, pertanian, spot untuk foto, homestay hingga memiliki kesenian tari yang bisa dijadikan sumber untuk menarik wisatawan. Desa Samiran juga memiliki karangtaruna dengan anggota aktif sebanyak $85 \%$. Selain itu juga memiliki PokDarWis (Kelompok Sadar Wisata), dan aspek infrasturktur lainnya seperti akses jalan, polsek, rumah sakit, minimarket hingga tempat ibadah.

2. Weakness (Kelemahan) :

Desa Samiran sudah memiliki website dan media sosial, seperti youtube namun masih sangat minimnya pembuatan konten yang digunakan untuk media promosi.

3. Opportunities (kesempatan) :

Masyarakat desa Samiran rata-rata sudah memilik gadget seperti smartphone dan sudah terbiasa untuk mengakses internet, serta keinginan dan kesadaran masyarakat desa Samiran sangat besar untuk mempromosikan Desa wisata Samiran

4. Threats (ancaman) :

Kesibukan masyarakat Desa Samiran dalam bekerja, karena rata-rata pemuda sudah berkeluarga dan bekerja sebagai petani, pedagang, buruh, atau melanjutkan pendidikan di luar kota.

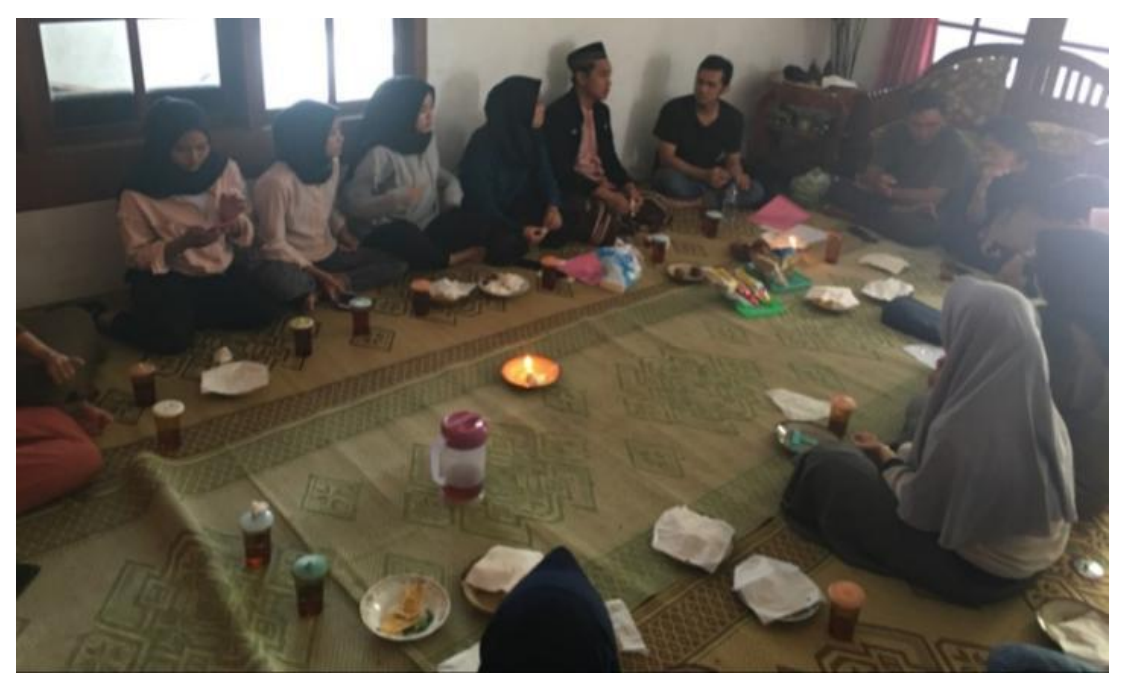

Gambar 2. Diskusi tentang potensi Desa Samiran

Kegiatan yang dilakukan pada gambar 2 memperlihatkan perwakilan warga dan tim pengabdian melakukan diskusi terkait apa saja potensi yang ada di Desa Samiran, kelemahan dan kelebihan apa yang dimiliki baik secara Sumber daya manusia maupun alamnya. Kemudian 
disepakati bersama bahwasanya Desa Samiran memiliki potensi wisata yang besar, mulai dari alamnya, pertanian, fasilitas, kesenian yang dikelola oleh warga. Desa Samiran memiliki kelebihan yaitu remaja yang jumlahnya lumayan banyak dan sudah mengenal internet namun masih memiliki kekurangannya dalam memaksimalkan kekuatan internet tersebut untuk kegiatan promosi. Hingga akhirnya muncullah disepakati untuk membuat program sosialisasi dan pelatihan pemanfaatan potensi warga khususnya remaja sebagai media untuk mempromosikan wisata dengan cara melakukan pelatihan pembuatan video $C J$ dengan menggunakan alat bantu smartphone atau gadget.

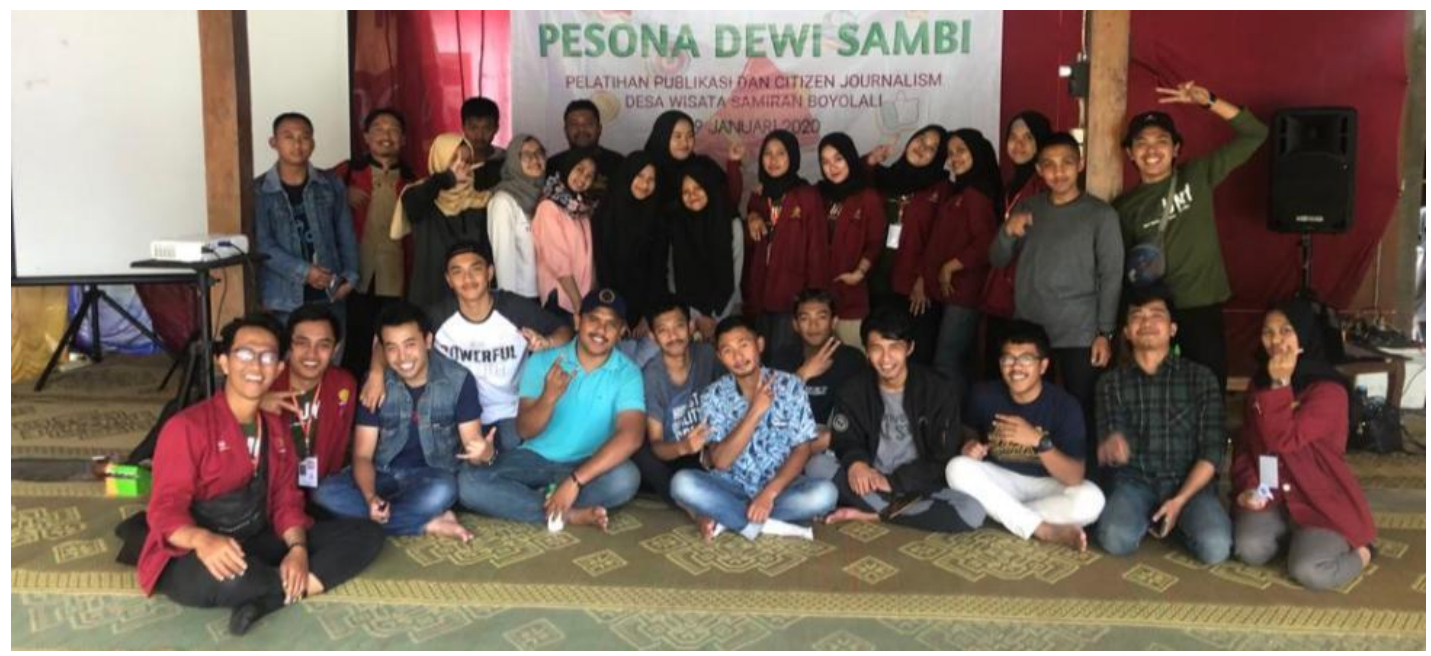

Gambar 3. Pelatihan dan pemahaman tentang citizen journalism

Pada gambar 3, memperlihatkan foto bersama antara warga dengan tim pengabdian setelah melakukan sharing tentang apa itu $C J$ dan workshop terkait bagaimana memproduksi video $C J$. Pada program ini masyarakat diharapkan semakin melek teknologi dan menjadi sadar akan pentingnya turut andil mempromosikan Desa Wisata. Sehingga dalam hal ini perlu bimbingan terkait bagaimana masyarakat meningkatkan berbagai skill untuk menunjang perkembangan Desa Wisata. Ada berapa materi yang disampaikan, antara lain :

a. Jurnalistik adalah pengumpulan bahan berita (peliputan), pelaporan peristiwa (reporting), penulisan berita (writing), penyuntingan naskah berita (editing), dan penyajian atau penyebarluasan berita (publishing / broadcasting) melalui media.

b. Jenis-jenis jurnalistik : Cetak, elektronik, online

c. Teknik jurnalistik ( $J$-Skill), adalah keahlian atau keterampilan khusus dalam hal reportase, penulisan dan penyuntingan berita, serta wawasan dan penggunaan bahasa jurnalistik atau bahasa media. Teknik reportase, news writing, news reporting, editing, Bahasa jurnalistik

d. Produk jurnalistik, meliputi berita, feature, opini 


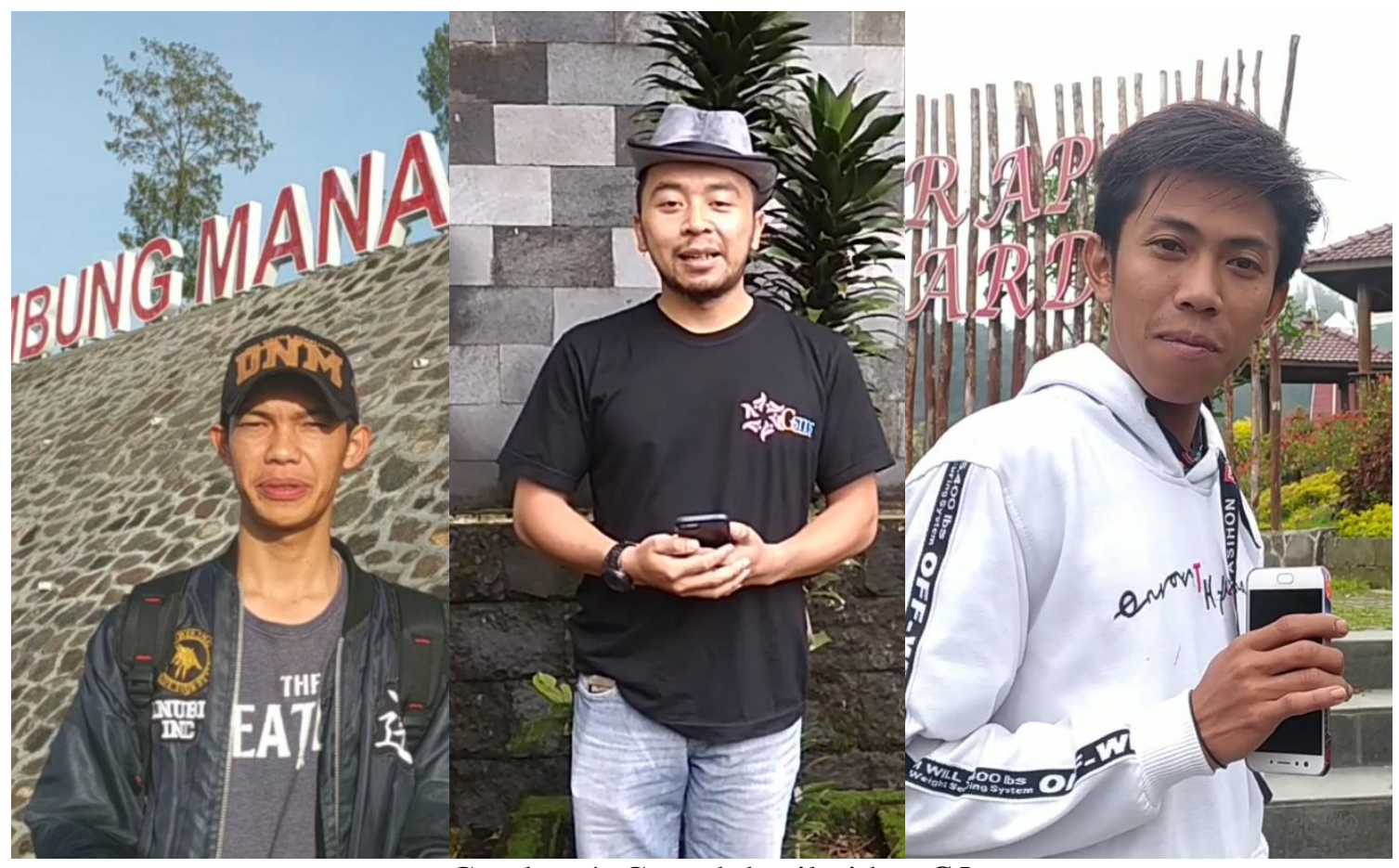

Gambar 4. Contoh hasil video $C J$

Gambar 4 adalah contoh hasil dari pembuatan video $C J$ yang diproduksi oleh warga dengan didampingi tim pengabdian. Produksi dilakukan sekitar 1 minggu mulai dari pengambilan gambar hingga editing dengan menggunakan alat yang ada, seperti handphone atau alat elektronik tambahan lainnya yang dimiliki oleh warga. Video yang terkumpul berjumlah 10 dengan melibatkan 2-4 warga dalam setiap produksinya dan berdurasi maksimal 5 menit. Jika dilihat dari jumlah video yang terkumpul, membuktikan bahwa minat warga khususnya remaja terbilang tinggi untuk mengikuti program pembuatan video $C J$.

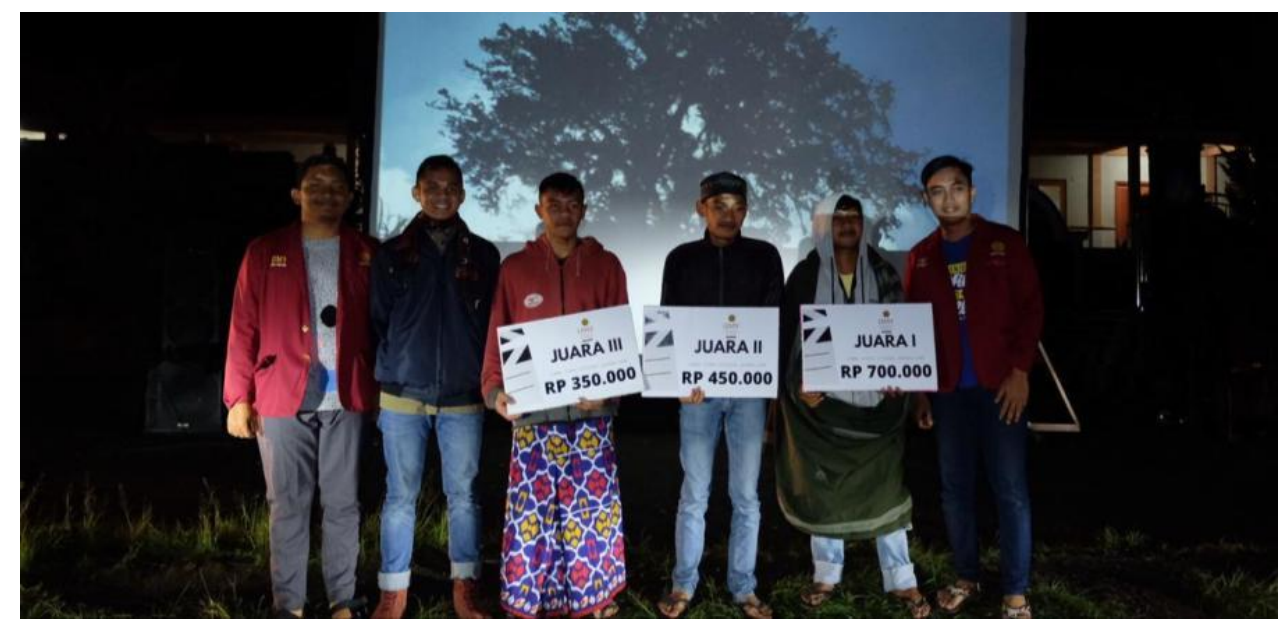

Gambar 5. Malam pemutaran video $C J$ 
Malam apresisi seperti gambar 5, terselenggara atas kerjasama dari pihak Bioling (Bioskop keliling) Universitas Muhammadiyah Yogyakarta yang dilakukan pada tanggal 3 februari 2020. Kegiatan ini dilakukan sebagai bentuk apresiasi dan terimakasih kepada warga Desa Samiran atas kerjasamanya selama kegiatan pengabdian berlangsung. Pada malam apresiasi ini, semua karya hasil pelatihan $C J$ diputar kemudian dipilih 3 juara. Kegiatan dihadiri oleh sebagain besar warga Desa Samiran.

Tabel 1. Pencapaian hasil dan target

\begin{tabular}{|c|c|c|c|c|}
\hline No & Masalah & Solusi & Target & Hasil \\
\hline 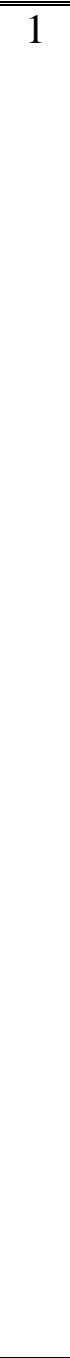 & $\begin{array}{l}\text { Kurangnya promosi } \\
\text { desa wisata dan } \\
\text { pemahaman } \\
\text { masyarakat tentang } \\
\text { pentingnya promosi } \\
\text { melalui media } \\
\text { elektronik }\end{array}$ & $\begin{array}{l}\text { Sosialisasi } \\
\text { tentang } \\
\text { publikasi atau } \\
\text { promosi online } \\
\text { dengan } \\
\text { memanfaatkan } \\
\text { media elektronik } \\
\\
\text { Pemanfaatan } \\
\text { media elektronik } \\
\text { (handphone, } \\
\text { gadget lainnya) } \\
\text { sebagai alat } \\
\text { pembuat konten } \\
\text { promosi }\end{array}$ & $\begin{array}{l}\text { Pemahaman } \\
\text { masyarakat } \\
\text { tentang } \\
\text { pentingnya } \\
\text { media } \\
\text { elektronik } \\
\text { sebagai alat } \\
\text { promosi, } \\
\text { mudah dan } \\
\text { tidak mahal } \\
\text { Memiliki } \\
\text { video } \\
\text { konten } \\
\text { promosi } \\
\text { wisata }\end{array}$ & $\begin{array}{l}\text { Sosialisasi } \\
\text { tentang potensi } \\
\text { masyarakat } \\
\text { sebagai salah } \\
\text { satu media } \\
\text { penyampai } \\
\text { informasi } \\
\text { dengan cara } \\
\text { program citizen } \\
\text { jurnalism } \\
\text { - Pelatihan } \\
\text { pembuatan } \\
\text { video citizen } \\
\text { journalism } \\
\text { dengan } \\
\text { menggunakan } \\
\text { handphone } \\
\text { Terciptanya } \\
\text { 10 video hasil } \\
\text { dari pelatihan } \\
\text { citizen } \\
\text { journalism } \\
\text { yang } \\
\text { diproduksi } \\
\text { oleh warga } \\
\text { Malam } \\
\text { apresiasi } \\
\text { karya }\end{array}$ \\
\hline
\end{tabular}

\section{Kesimpulan}

Berdasarkan kegiatan pendampingan dan pelatihan citizen journalism sebagai media promosi wisata Desa Samiran, dapat disimpulkan sebagai berikut :

1. Warga Desa Samiran, khususnya remaja semakin memahami pentingnya media promosi dan menyadari bahwa untuk memproduksi konten video promosi tidak harus mahal dan tidak susah

2. Warga mendapatkan pengetahuan lebih tentang apa itu citizen journalism $(C J)$ 
3. Warga dapat memanfaatkan media elektronik yang ada, seperti smartphone sebagai alat untuk memproduksi konten-konten video sebagai bahan untuk promosi Desa Wisata Samiran.

4. Diharapkan warga desa Samiran semakin banyak memproduksi video terutama CJ demi kemajuan desa wisata Samiran.

\section{Daftar Pustaka}

[1] Pendit, Nyoman S. (2003). Ilmu Pariwisata Sebuah Pengantar Perdana. Jakarta: Pradnya Paramita, 20.

[2] Wikipedia, "Pariwisata berkelanjutan", https://id.wikipedia.org/wiki/Pariwisata_berkelanjutan\#cite_note-1, diakses pada 28 mei 2020, pukul 13.27 WIB.

[3] Romli, A. S. (2012). Jurnalistik Online. Bandung: Nuansa Cendikia, 11.

[4] Abdilah Fitra dan Leksmono, S Maharani (2001).Pengembangan Kepariwisataan berkelanjutan. Jurnal Ilmu Pariwisata 6 (1), 87.

[5] Adi, Isbandi rukminto. (2007). Intervensi Komunitas Pengembangan Masyarakat Sebagai Upaya Pemberdayaan masyarakat.Jakarta : PT Rajagrafindo Persada, 27.

[6] Nofriya. (2016). Peran Masyarakat dalam Mewujudkan Pariwisata Hijau di Sumatera Barat. Padang. Jurnal Seminar Nasional Sains dan Teknologi Lingkungan II, 62.

[7] Nurudin. (2009). Jurnalisme Masa Kini. Jakarta : Rajawali Press, 215.

[8] Nurul, Hasfi. (2009) Studi Kasus tentang Perkembangan Citizen Journalism di Indonesia. Project Report. DIPA Fisip http://eprints.undip.ac.id/33925/, di akses tanggal 28 mei 2020, pukul 22.00 WIB

[9] Zuhri, Nizwan, Dwi Haryadi dan Jamilah Cholilah. (2015). Brandingisasi Pariwisata, Yogyakarta: Istana Media, 7-8.

[10] Nugraha, Pepih. (2012) Citizen Journalism Pandangan, Pemahaman, dan Pengalaman. Jakarta : PT. Kompas Media Nusantara, 75. 